\title{
Effect of sodium selenite on male Sprague-Dawley rats exposed to sublethal dose of cadmium chloride
}

F Jabeen $^{1,2}$, A S Chaudhry ${ }^{1}$

${ }^{1}$ Newcastle University, Newcastle Upon Tyne, United Kingdom, ${ }^{2}$ GC University, Faisalabad, Pakistan

Email:f.jabeen@newcastle.ac.uk

Introduction Cadmium $(\mathrm{Cd})$ is a dangerous occupational and environmental toxin which can affect livestock and human health. It accumulates in liver and kidneys of $\mathrm{Cd}$ exposed animals and humans. Cadmium half-life is about 10 years, so the symptoms of cadmium intoxication may occur several years after the exposure. Selenium (Se) is generally recognized as an important antioxidant with numerous protective biological functions. The principal role of Se is associated with the control of lipid peroxidation because this trace element is a component of selenoenzymes contributing to the antioxidant system. In spite of intense research during recent years, the role of this microelement needs further elucidation. Therefore this study examined the role of $\mathrm{Se}$ as Sodium selenite in minimising the harmful effects of Cadmium chloride in male SpragueDawley rats.

Materials and methods Following approval by the Quaid-i-Azam University Islamabad, Pakistan's Ethics Committee, twenty male Sprague Dawley rats (28 days old) were housed at the animal unit of this University. The rats were acclimatized to their housing and feeding for two weeks before they were weighed and distributed into four groups of 5 rats each with similar initial body weight (BW) per group. These rat groups were randomly housed in steel cages $(38 \times 23 \times 10 \mathrm{~cm})$ which were maintained in a room at $25 \pm 2^{\circ} \mathrm{C}$ with dark to light cycle of 14 to 10 hours. A same commercial diet and fresh water was available ad libitum to these rats throughout this study. The rats were injected with subcutaneous doses (1mg $/ \mathrm{kg}$ BW) of normal saline (Control), Cadmium Chloride (Cd group), Sodium selenite (Se group) and Cadmium chloride + Sodium selenite (Cd-Se group) on alternate days for four weeks of this study. All rats were then weighed at weekly intervals for four weeks before their sacrifice on $29^{\text {th }}$ day, to collect their blood, livers and kidneys. The livers and kidneys were weighed and these weights were expressed as $\mathrm{g} / 100 \mathrm{~g}$ final BW. Cd and Se contents in blood, liver and kidneys were determined by atomic absorption and haemoglobin $(\mathrm{Hb})$ in blood was determined by a spectrophotometer. The data were then statistically analysed as a completely randomised design with repeated measures for body weight by using ANOVA in Minitab software. The analysis compared the effect of above mentioned treatments on weekly BW, tissues and metals in different tissues at $\mathrm{P}<0.05$. Tukey's test was used to compare treatments means at $\mathrm{P}<0.05$.

Results Table 1 shows significant differences between different treatments for mean weekly BW from week 2 onwards and different tissues of rats $(\mathrm{P}<0.05)$. While the initial mean BW of rats was similar, it was lower for Cd $(>0.05)$ but greater $(\mathrm{P}<0.05)$ for Se than the control group for most weeks. The Cd-Se rats showed more comparable BW to the control group. The mean liver and kidney weights and $\mathrm{Hb}$ were significantly lower in the $\mathrm{Cd}(\mathrm{P}<0.05)$ than the Control, Se and $\mathrm{Cd}-\mathrm{Se}$ groups $(\mathrm{P}<0.05)$ but these did not differ between the $\mathrm{Cd}-\mathrm{Se}$ and Control groups $(\mathrm{P}>0.05)$. Table 2 shows that the $\mathrm{Cd}$ contents were many folds higher in blood, kidneys and livers for the $\mathrm{Cd}$ than the control group whereas it was below the detection limit in Se group. While Cd content in livers and kidneys for the Cd-Se group was many fold higher than the control group it was lower than the Cd group.

Table 1 Weekly (W) mean BW (g), liver and kidney weights $(\mathrm{g} / 100 \mathrm{~g} \mathrm{BW})$ and $\mathrm{Hb}(\mathrm{g} / \mathrm{dL})$ of rats for different treatment groups

\begin{tabular}{|c|c|c|c|c|c|}
\hline & Control group & Cd Control & Se group & Cd-Se group & SEM \\
\hline Initial BW & 86.2 & 86.6 & 86.2 & 83.5 & 2.81 \\
\hline W1 & $111.2^{\mathrm{ab}}$ & $105.8^{\mathrm{a}}$ & $122.2^{b}$ & $112.3^{\mathrm{ab}}$ & 3.00 \\
\hline W2 & $146.6^{\mathrm{a}}$ & $136.2^{\mathrm{a}}$ & $166.2^{b}$ & $147.8^{\mathrm{a}}$ & 3.70 \\
\hline W3 & $185.4^{\mathrm{b}}$ & $170.6^{\mathrm{a}}$ & $218.6^{\mathrm{c}}$ & $192.8^{b}$ & $3.84^{* *}$ \\
\hline W4 & $217.6^{b}$ & $199.8^{\mathrm{a}}$ & $258.0^{d}$ & $226^{\mathrm{c}}$ & $3.83^{* * *}$ \\
\hline Liver & $4.73^{b c}$ & $4.08^{\mathrm{a}}$ & $4.85^{c}$ & $4.69^{b}$ & $0.06^{* * *}$ \\
\hline Kidney & $0.87^{\mathrm{b}}$ & $0.70^{\mathrm{a}}$ & $0.80^{\mathrm{b}}$ & $0.80^{\mathrm{b}}$ & $0.02^{*}$ \\
\hline $\mathrm{Hb}$ & $12.34^{b}$ & $10.38^{\mathrm{a}}$ & $14.06^{\mathrm{c}}$ & $12.35^{b}$ & $0.16^{* * *}$ \\
\hline
\end{tabular}

(Means with similar letters in columns did not differ significantly; $*=P<0.05 ; * *=P<0.01 ; * * *=P<0.001$ )

Table 2 Mean Cadmium (Cd) and Selenium (Se) contents $(\mathrm{mg} / \mathrm{kg})$ and SEM in different rat tissues for different treatment groups

\begin{tabular}{lllllllllll}
\hline Tissues & \multicolumn{4}{c}{ Cadmium Contents } & \multicolumn{4}{c}{ Selenium Contents } \\
& Control & Cd & Se & Cd-Se & SEM & Control & Cd & Se & Cd-Se & SEM \\
\hline Blood & $0.03^{\mathrm{a}}$ & $0.07^{\mathrm{b}}$ & ND & $0.10^{\mathrm{c}}$ & $0.002^{* * *}$ & 3.73 & 2.93 & 2.90 & 2.40 & 0.30 \\
Kidney & $0.02^{\mathrm{b}}$ & $3.50^{\mathrm{a}}$ & ND & $3.05^{\mathrm{a}}$ & $0.17^{* * *}$ & $2.60^{\mathrm{b}}$ & $3.70^{\mathrm{c}}$ & $3.40^{\mathrm{bc}}$ & $1.40^{\mathrm{a}}$ & 0.32 \\
Liver & $0.02^{\mathrm{b}}$ & $4.17^{\mathrm{a}}$ & ND & $3.71^{\mathrm{a}}$ & $0.172^{* * *}$ & $2.92^{\mathrm{a}}$ & $2.42^{\mathrm{a}}$ & $2.42^{\mathrm{a}}$ & $1.13^{\mathrm{b}}$ & 0.31 \\
\hline \hline
\end{tabular}

(Means with similar letters in columns did not differ significantly; $* * *=P<0.001$ )

Conclusion This study indicates that selenium in the form of Sodium selenite may have a protective effect against cadmium chloride induced toxicity in male Sprague-Dawley rats.

Acknowledgements Farhat Jabeen thanks Islamic Development Bank Jeddah, Saudi Arabia for funding this post-doctoral research, Professor Dr. Samina Jalali for providing research facilities at Quaid-i-Azam University, Islamabad, Pakistan and Dr. Sarwat Jehan, QAU, Islamad, Pakistan for providing Sprague Dawley rats. Riffat Gillani and Noshaba Memon are acknowledged for their help and cooperation during animal trial at QAU, Islamabad, Pakistan. 